\title{
Indonesian Digital Governance Pillars
}

\author{
Ayuning Budiati ${ }^{1}$, Ipah Ema Jumiati ${ }^{2}$ \\ University of Sultan Ageng Tirtayasa, Indonesia \\ \{ayoekomara@gmail.com¹, ayuningbudiati@untirta.ac.id²\}
}

\begin{abstract}
Based on regulation No 19 Year 2016 and Government Regulation No 20 Year 2016, the Indonesian Government under The Ministry of Communication and Information has four pillars, namely digital ethics, skills, culture and security. However, e-governance in Indonesia needs more efforts to enhance infrastructure. digital literacy or electronic literacy (e-literacy) to enhance digital governance implementation in this country. This research uses descriptive analytics method and qualitative approach/ The result of this result is despite four pillars in Indonesian Digital Governance, there is a need for the fifth pillar namely, multi helix collaboration (among government -central and local government-, private sector, media, academics, society and other communities).
\end{abstract}

Keywords: digital culture; ethics; skills; security pillars; collaboration.

\section{Introduction}

E-governance is decisions in using the internet to improve public service deliveries. It is regarding kind decisions, who is making decisions and how decisions are being made. Therefore, e-governance is how to manage e-government. Whilst e-government is the use of the internet by the government to provide public services. E-government is generally related to the use of the internet. Thus, e-government generally means the development of internet-based solutions for government services. E-government can also be defined in relation to the policymaking process and citizen involvement. E-government is characterized by interorganizational relationships including policy coordination, policy implementation and by the delivery of services online or through other electronic means to citizens (United Nations, 2001:54).

\section{Research Methods}

In carrying out the research on Indonesian digital governance pillars, the researcher established a descriptive qualitative approach. This choice is based on the reason that the approach is in line with research problems in the process of establishing the Indonesian government's digital governance pillars. As stated by Bungin (2008:69) that a descriptive qualitative approach is suitable to be used to provide an overview of research problems in determining the pillars of digital governance of the Indonesian government. Through this approach, an understanding and explanation from the research field is also built. In this regard, the phenomenon of the process and explanation of meaning becomes the main method in this research. 
The consideration of using a descriptive qualitative approach in this research is to obtain complete and comprehensive and in-depth data on how and why various versions can appear in the determination of the Indonesian government's digital governance pillars and trigger problems in them. By using a qualitative approach, reformulation and reconceptualization of the theory of policy implementation will be obtained, both in terms of the object being studied and the views of the researchers themselves, by combining ethical and emic approaches like the modern qualitative paradigm. In time, new hypothetical propositions will be obtained through the meaning of interactions between attributes and properties which are then needed as the foundation for building categories and providing explanations of research phenomena.

In this study, the sources of information are WhatsApp Group (WAG) users, online communities, webinars. Informants as conveyed by Bungin (2008: 76) research informants are people who understand information and research objects, namely the main actor or other people who understand the research object. The informants were obtained based on the consideration of the function and role of the informants according to the focus of the research problem, not based on the number needed. Subject informants are those who are directly involved in the process of establishing the Indonesian digital governance pillars. Interviews were conducted many times and there were also informants who were interviewed within certain limits and categories, for triangulation in strengthening the data that was previously up to saturation, in order to complete the research.

\section{Indonesian Digital Governance Pillars}

At present, e-governance implementation in Indonesia is focused on improving public services by digital platforms, such as YouTube, Tik Tok, and applications. Moreover, many webinars and the use of zoom and google meet very high numbers due to pandemics and work from home policies. The aims are to reduce costs and improve transparency, but the most important aim is to make public service accessible for all citizens and precautions from Covid 19 diseases. E-governance to make life easier, more transparent, accountable, efficient and effective. Indonesia internet users especially during this pandemic era are increasing. Herewith, the table of Indonesian internet users:

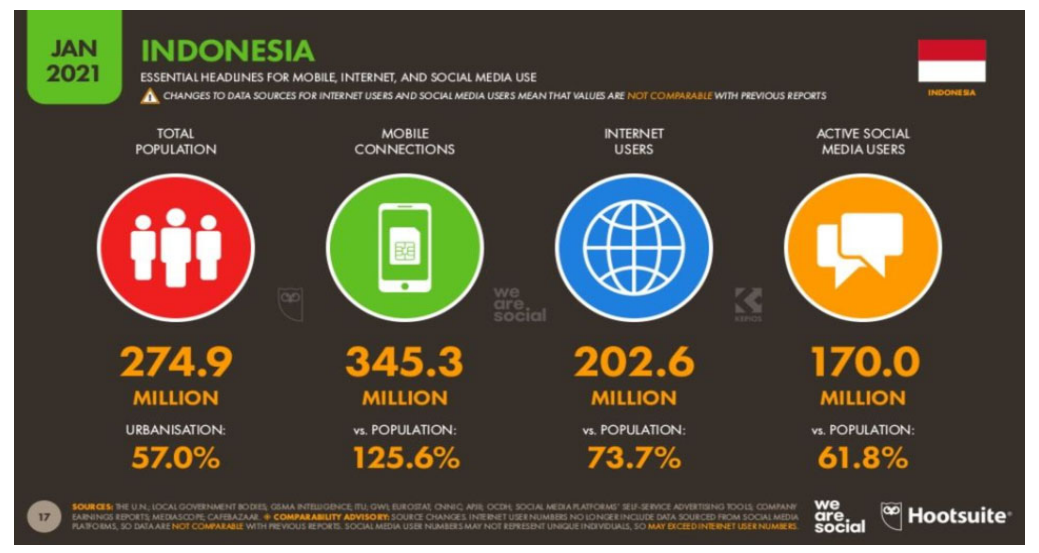

Source.https://www.google.com/search?q=indonesia + internet + user\&rlz=1C1CHNY_enID80 8ID808\&source, 2021. 
According to the above diagram, Indonesia's internet users in the year 2020 is 202.6 million, whilst the mobile connection is 345.3. It shows that one person in Indonesia can have more than one mobile phone. Moreover, social media users are 170 million. Therefore, improving digital governance or electronic governance among multi helix actors in Indonesia is one strategic action. Multihelix is an actor in development, namely government, private sectors, society, media, academics and other social organizations. Using e-government will give advantages such as efficiency, effectiveness, and transparency. As the United Nations (2001, p. 5) states, e-government can create better service delivery to citizens and business, reducing corruption by increasing transparency and social control. In other words, e-government can improve the government's capacity to serve their citizens.

Based on the research, the greatest number of users of social media in the year 2021 in Indonesia is YouTube and followed by WhatsApp. This shows that digital government can be more effective by using this social media. The number of WhatsApp user shows in this table:

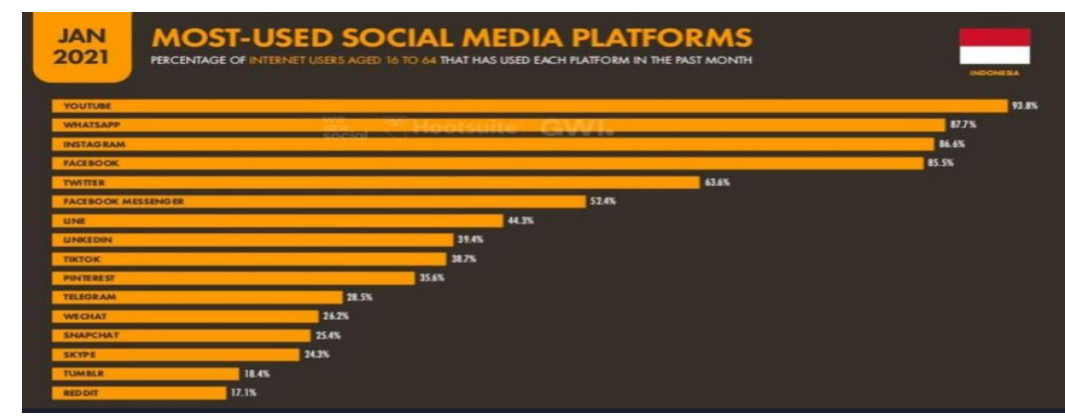

Moreover, the use per person in their daily life for the internet is on average eight hours with time using social media is on average three hours. Moreover, on average from 207 million internet users in Indonesia from 270 million population meaning, on average one Indonesian has more than one gadget. E-governance has become more important in Indonesian literacy or our digital literacy. As we know that according to the Microsoft research in year 2020, Indonesian is the rudest people in South East Asian in digital literacy, such as numbers of hoax increase $13 \%$ and hate speech also increase (Microsoft, 2021).

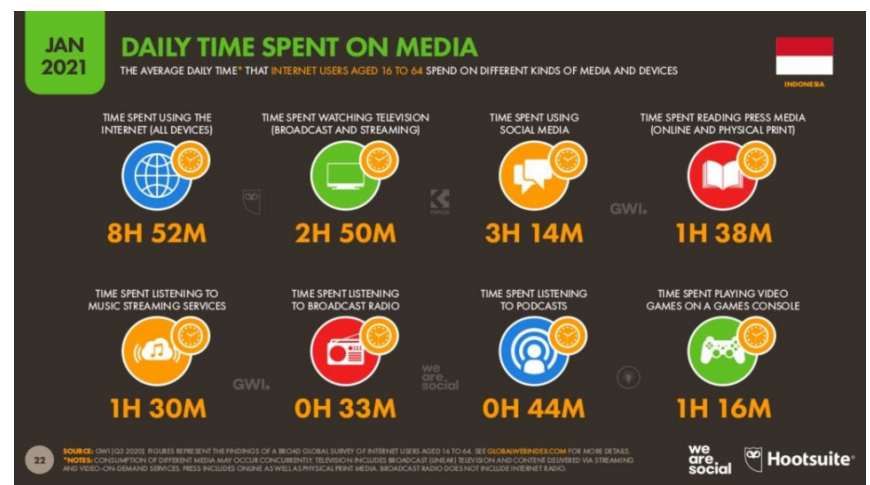

Source.https://www.google.com/search?q=indonesian+social + media + users\&tbm $=$ isch\&ved $=2$ ahUKEwi-6Zqp, 2021. 
Furthermore, the digital government index in Indonesia shows below that the government of DKI Jakarta is the highest $(93,93)$ while Papua is the lowest (31). There is a need for more improvement and collaboration among multi helix actors in improving e-governance, especially in aspects of infrastructure, human resource, bureaucratic culture and leaders commitment (Budiati, 2003).
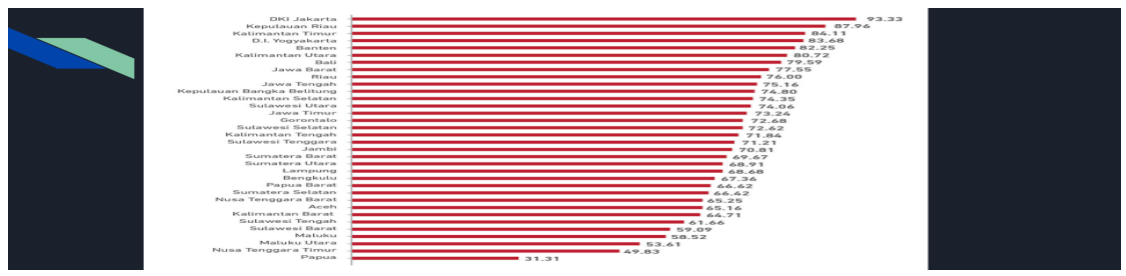

Herewith, four Indonesian digital governance pillars

(https://www.google.com/search?q=indonesian+digital+pillars\&tbm=isch\&ved=2ahUKEwjR wciD0sLz, 2021), namely digital ethic, culture, skills and security:

Kerangka Literasi Digital(1/3)

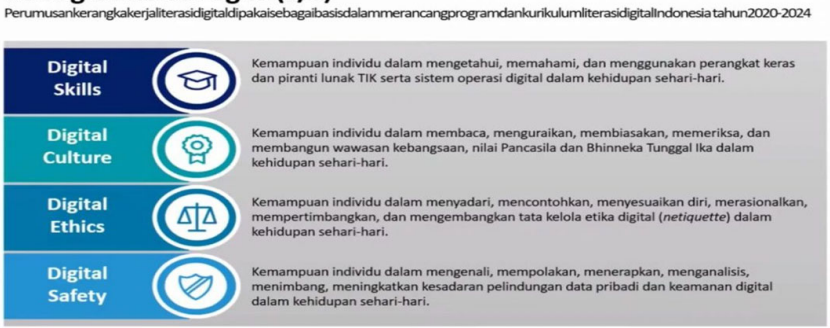

The first pillar is digital ethic:

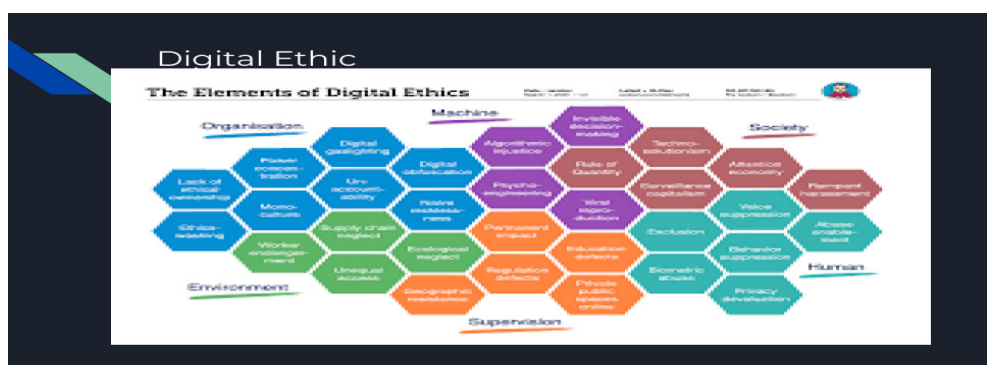

Digital ethics is a set of values that we should use as the foundation for our activities in using the internet. In the digital world we name it netiquette. Such as, not sharing hoaxes, conducting cyber bullying or even phishing and spamming. Further pillars are digital culture. Digital culture is the culture that we used in using the internet. It is behavior and attitude in our daily basis in using the internet in a positive way and productive output and outcome. 


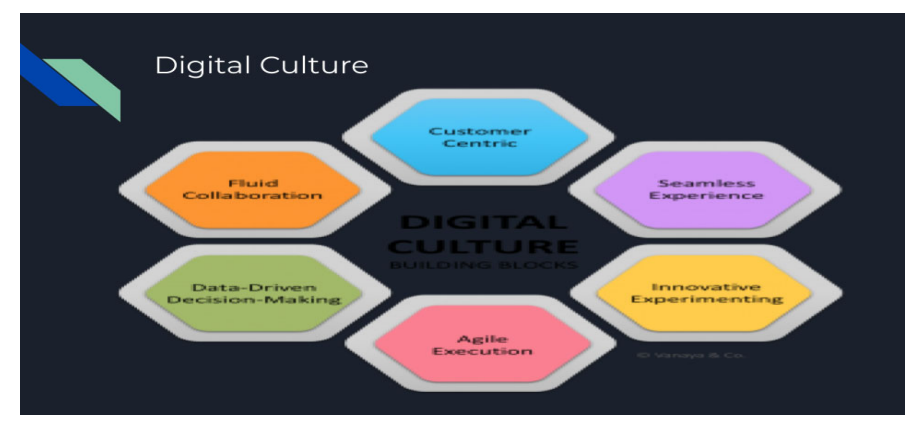

Furthermore, there is a digital safety pillar. Digital safety pillar is a set of skills that the internet users need to have and use regularly when they connect with the internet. It is for our own benefit when we constantly use safety internet precautions, actions and evaluation or further actions.

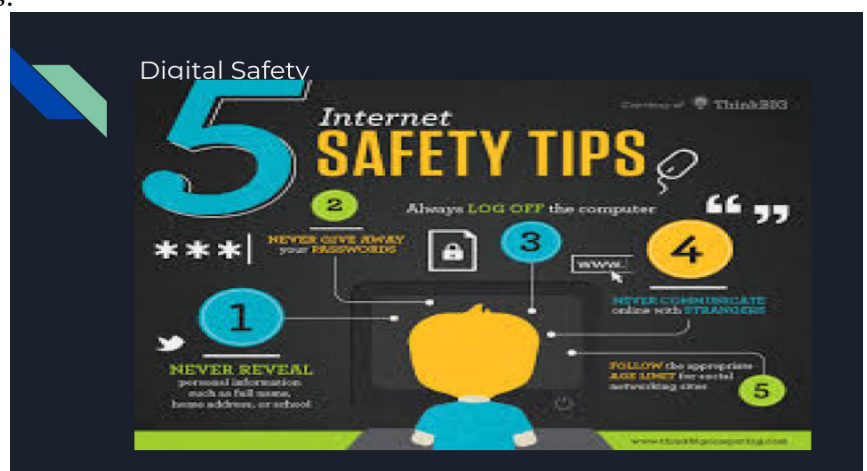

Some digital safety activities are to use unique and strong passwords, activate two authentication numbers, use one time password and not share it to anyone, not sharing hoaxes and beware of spam and phishing by making careful attention to domain and $u r l$ address. Moreover, according to the Theory $U$ in improving e-government there is a need for collaboration (Schurmer,O: 2014). Collaboration among multi helix actors will boost digital governance in Indonesia e-government implementation.

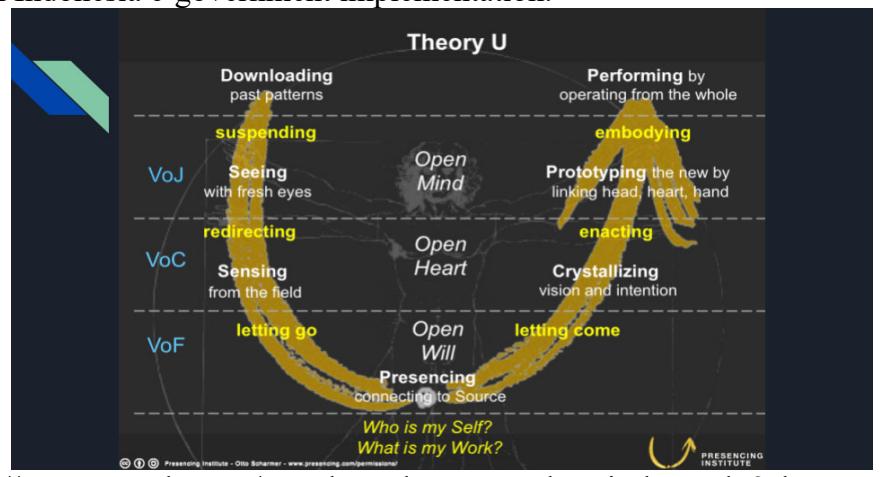

Source.https://www.google.com/search?q=theory+u\&tbm=isch\&ved=2ahUKEwjgmcWlzsLz AhXTn0s, 2021. 
Based on U Theory, collaboration will create better by conducting open mind, open heart and open will. And also supported by process namely, seeing by using open mind, sensing by open heart and presenting, crystallizing and embodying, and finally collaboration.

\section{Conclusions and Recommendations}

Pillars in Indonesian Digital Governance are collaborations, digital skills, ethics, culture and safety to enhance transparency, accountability, effectiveness and efficiency of public service deliveries. Collaboration in multi helix actors form namely the government (central and local government), private sector, society, media, academics, religions actors, communities should be embraced to enhance e-governance implementation in Indonesia. More collaboration among multi helix actors in enhancing e-governance implementation in Indonesia. Leveraging religious institutions such as churches and mosques' role in collaboration in providing free $\mathrm{Wi}-\mathrm{Fi}$ for people' needed.

\section{References}

[1] Bungin, Burhan. 2008. Penelitian Kualitatif, Komunikasi, Ekonomi, Kebijakan Publik, dan Ilmu Sosial Lainnya. Jakarta: Kencana Prenada Media Group.

[2] Gronlund, A. (2002), Electronic Government: Design, Applications and Management, Idea Group Publishing, Hershey.

[3] Hughes, O. E. (2003), Public Management \& Administration: An Introduction, Palgrave Macmillan, New York.

[4] KDI School of Public Policy \& Management, OECD (Organization for Economic Cooperation \& Development), Korean Ministry of Planning \& Budget. (2003), International Seminar on Open Government, KDI School, OECD, Korean Ministry of Planning \& Budget, Korea.

[5] Komara, Rudiat.2007. Report: IT Governance in Indonesia. Jakarta: SPIMNAS LAN Jakarta

[6] Layne, K. \& Lee, J. (2001), "Developing Fully Functional E-government: A Four Stage Model”, Government Information Quarterly, No. 18, pp.122-136.

[7] Laudon, K.C \& Laudon, J.P. (1998), Information Systems and the Internet, A Problem-Solving Approach, The Dryden Press, Harcourt Brace College Publishers, Fort Worth, Philadelphia.

[8] Marche, S \& McNiven, J.D. (2003), "E-government and E-governance: The Future Isn't What It Used To Be", Canadian Journal of Administrative Science, Vol. 20, No. 1, pp. 74-86.

[9] OECD (Organization for Economic Co-operation and Development). (2003), The E-government Imperative, OECD Publications Services, Paris.

[10] Prins, J.E.J. (Eds). (2001), Designing E-government, On the Crossroads of Technological Innovation and Institutional Change, Kluwer Law International, Netherlands.

[11] Setiadi, Kompas, 16 Mei 2005, Pelayanan Publik di Indonesia, Jakarta.

[12] Sinar Harapan, October 2005, Indonesia Negara Terkorup Ke Enam, Jakarta.

[13] Smith, R.F.I, Can E-government Help?, 2005, Monash University, Melbourne.

[14] The Asian Development Bank, E-government to Combat Corruption in the Asia Pacific Region, http://www.adb.org/Governance/egovernmentcorruption.pdf, May 2003, [date accessed: 10 October 2003].

[15] The United Nations, Benchmarking E-government: A Global Perspective, http://unpan1.un.org/intradoc/groups/public/documents/un/unpan003984.pdf, 2001, [date accessed: 21 January 2003].

[16] The United Nations. (2003), World Public Sector Report 2003: E-government at the Crossroads, The United Nations, New York. 
[17] The World Bank, The E-government Handbook for Developing Countries, A Project of InfoDev and The Center for Democracy and Technology, http://wwwl.worldbank.org/publicsetor/egov/Egov\%20Handbook.pdf, 2003, [date accessed: 10 November 2003].

[18] Victorian Government, Multi Media Victoria, Putting People at the Centre, Government Innovation Working for Victorians, http://www.mmv.vic.gov.au, 2002, [date accessed: 24 February 2004].

[19] Wahyudi, I.A., Indonesian E-government, http://www.eov.thai.gov.net/knowledge/eGovernmentInter/INA.ppt, November 2001, [date accessed: 29 January 2003].

[20] Weill, P \& Vitale, M.R. (2001), Place to Space, Migrating to eBusiness Models, Harvard Business School Press, Boston, Massachusetts.

[21] Weill dan Ross, (2004), IT Governance, How Top Peformers Manage IT Decision Rights for Superior Results, Harvard Business School Press, Massachusetts.

[22] Wibisono, Y \& Sulistyaningsih, W, The Development of E-government in Indonesia, http://www.uncrd.or.jp/ict/eworkspace/papers/dp_woro.htm, 2002, [date accessed: 31 January 2003].

[23] Yong, J.SL. (Eds.) (2003), Enabling Public Service Innovation in the 21st Century: E-government in Asia, Times Media Private Limited, Singapore. 